RAD Conference Proceedings, vol. 2, pp. 265-268, 2017

www.rad-proceedings.org

\title{
ERYTHROCYTES AND DNA STUDY VIA OPTICAL MICROSCOPY
}

\author{
N.V. Kamanina ${ }^{1,2 *}$, S.V. Likhomanova1, A.A. Kamanin3 \\ ${ }^{1}$ Joint-Stock Company "Vavilov State Optical Institute", Saint Petersburg, Russia \\ ${ }^{2}$ St. Petersburg State Electrotechnical University "LETI", Saint Petersburg, Russia \\ 3Pavlov First Saint Petersburg State Medical University, Saint Petersburg, Russia
}

\begin{abstract}
The physical phenomena resulting from forces exerted on a liquid-crystal mesophase on the account of the electric, magnetic, thermal fields and deformation are due to the weak intermolecular interaction of the structural elements of liquid-crystal media. In order to take an advantage of the factors, such as the presence of weak dispersion forces between the molecules of liquid crystals and the high orienting ability, the liquid-crystal anisotropic medium has been considered for visualizing, fixing, and orienting human red blood cells and DNA. The feedback mechanism of the liquid crystal self-organization has been discussed, due to the interaction with erythrocytes; moreover, the spectral features of the LC with DNA have been shown. In the present paper, the special accent will be on the orientation of these types of the bio-objects under the conditions in which the interface between solid and liquid crystal mesophase is modified via laser oriented deposition technique, as well as by using the surface electromagnetic waves treatment. It provokes the best visualization and orientation of the bio-objects in the anisotropic liquid crystal media when the direct orienting polymer coatings have been removed.
\end{abstract}

Key words: Liquid crystal, erythrocytes, DNA, self-arrangement, refractive features, interface, nano- and biostructuring

DOI: $10.21175 / \operatorname{RadProc} .2017 .54$

\section{INTRODUCTION}

It is well known that, at the present time, so many scientific investigations are related to the study of the bio-objects in order to modify the physical and chemical properties of the conjugated organic materials and to predict their use in the general optoelectronics, display and biomedicine [1-6]. Our own steps in this direction occupy a special place, because the liquid crystal (LC) structures with the good orienting ability have been successfully applied and different interface conditions have been proposed [7-11].

\section{EXPERIMENTAL CONDITIONS}

The LC matrix compounds from the class of cyanobiphenyls, which have been sensitized with the intermolecular charge transfer complex based on 2cyclooctylamino-5-nitropyridine (COANP)-C70, have been used in order to increase the polarization features. The red blood cells stable in sodium citrate, as the bio-objects, have been incorporated in this nanostructured LC mixture. The ratio of LC solutions to solutions of sodium citrate with the red blood cells has been 5:1. The red fish DNA content in water has

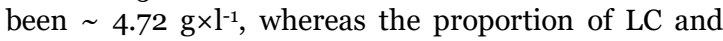
DNA water solution has been 5:1. This mixture has been placed in 10 micrometer thick glass cells in order to observe the erythrocytes with the dimension of 5-8 micrometers with good advantage. Both glass substrates have been coated with the conducting ITO coatings.

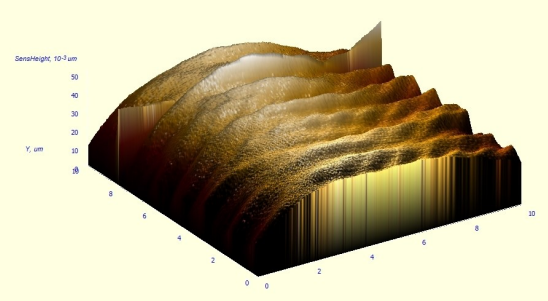

Figure 1. AFM-image of the structured relief modified at the electric field of $100 \mathrm{~V} \times \mathrm{cm}^{-1}$ and treated with SEW

To mitigate the toxicity of orienting polyimide coating put before on the conducting ones, now the glass substrates, coated with an ITO-layer deposited via the non-contact laser technique, have been prepared. Moreover, the ITO relief has been modified by oriented CNTs in the electric field of $100-600 \mathrm{~V} \times \mathrm{cm}^{-1}$ with the following additional treatment by the surface electromagnetic wave (SEW) processing. Some view of

\footnotetext{
"nvkamanina@mail.ru
} 
the obtained relief is shown in Fig. 1. It should be mentioned that the penetration depth has depended on the applied electric field.

CNTs single-walled, \#704121-250MG, carbon $90 \%$, a diameter of $0.7-1.1 \mathrm{~nm}$ have been purchased from Aldrich Company. The $\mathrm{CO} 2$ laser with the power of $\sim 30$ $\mathrm{W}$, the width of the spot of radiation is $\sim 5 \mathrm{~mm}$, the velocity of the beam $\sim 2-4 \mathrm{~cm} \times \mathrm{s}^{-1}$ has been used for the deposition procedure. The laser oriented deposition (LOD) technique has had some advantage due to its applying permits to partially eliminate the interface between the air and solids and it has dramatically decreased the Fresnel losses [12-14].

\section{RESULTS AND DISCUSSION}

In the study of the orientation of the red blood cells and DNA in the LC-media, the following images shown in Fig. 2a and Fig. 2b have been obtained. The dimension shown in Fig. 2a is corresponded to 30 micrometers. Thus, it permits to check the size of the erythrocytes very easily. The scale to check the DNA is shown inside the photos presented in Fig. 2 b.

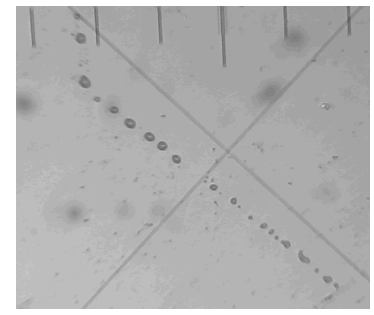

$a$

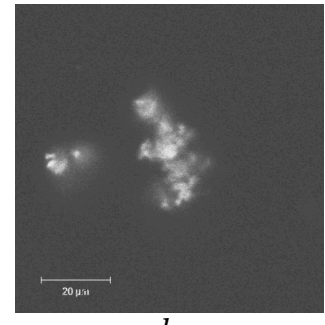

$b$
Figure 2. Optical microscopy image of the erythrocytes orientation in the liquid crystal $(a)$ and high resolution visualization of the DNA structure in the LC $(b)$

It should be remarked that some information and experimental results about the refractive property change of the LC+DNA structure has been done before in the Ref.15; now the direct evidence of the configuration check of the DNA form in the LC is shown (Fig. 2b)

Analyzing the results of the erythrocytes orientation in the LC media (Fig. 2a), one can testify that erythrocytes can follow the LC-dipoles since the shell of the erythrocytes accumulates some charge. This process can provoke possible interaction between erythrocytes and the LC-dipoles and change the order parameters of the composite. Moreover, the orientation procedure can testify the configuration of the erythrocytes and their deformation, which permits to the medical personnel to calculate the number of the erythrocytes with the normal form with good advantage. Furthermore, after about three weeks, an almost complete dissolution of red blood cells in the liquid crystal has been observed. This may be due to the destruction of the shell of a red blood cell and moving the cell contents in the LC-mesophase. A quality model, responsible for the process discussed, is shown in Fig. 2. The orientation of erythrocytes in a liquid crystal (Fig. 3, left photo and below shown picture), partial dissolution (Fig. 3, central photo and picture), and complete dissolution in the LC (Fig. 3, right photo and picture) are presented.

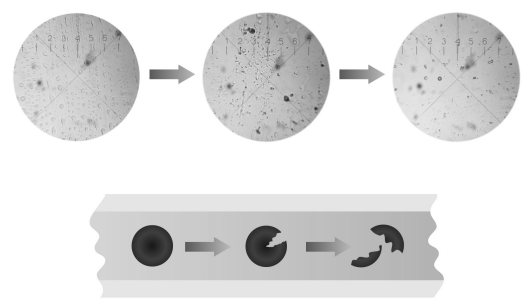

Figure 3. Photos and quality model of the orientation and dissolution of the red blood cell in LC

Let us discuss the following aspect. Blood reacts to the extremely multifarious processes that are triggered in an organism by various external factors or by a change in the number or activity of the cells circulating in the blood, by the state of the liquid phase, and by the reactivity of these components in relations to the physical factors of the medium. Generally, the configuration of the red blood cells (erythrocytes) is an important indicator of the health of patients, along with the color and the hemoglobin concentration of the blood. It should be remembered that a healthy human red cell is disk-shaped. A transformation of the erythrocytes can result in energy and immunological imbalances. An elevation of the count of transformed cells is a deleterious factor that can lead to a number of pathological processes in the human organism. A judicious choice of the medium, into which the erythrocytes are placed, will make it possible to determine both the number and shape of the cells rather simply. Thus, a simple visualization process of the erythrocytes in the LC mesophase can be considered as the perspective express-method to make the diagnosis about the erythrocytes form. According to the DNA visualization, one can testify that the LCmedia, as the water soluble one, can be chosen as an alternative structure to make the biomedical experiments with DNA.

Moreover, using the novel LOD technique one can establish the absence of a toxic solvent presented in the previously used orienting polymer layers for aligning the anisotropic LC-dipoles along a created relief. Thus, in the current research, the relief obtained via LOD procedure has the good advantage among previously used ones because it does not provoke the deformation of the red blood cells form and DNA.

\section{CONCLUSIONS}

To summarize the results of this research, the following should be concluded:

1). Liquid crystal media can be proposed and advocated as the effective bio-compatible systems to put the bio-objects inside it.

2). Liquid crystal media can provoke the orientation of the human red blood cells and red-fish DNA in this mesophase with good advantage. 
3). Orientation process can be coincided with the visualization one which permits to test the form of the studied bio-objects with good advantage.

4). Approximate time interval of the complete erythrocyte dissolution in the LC materials has been established and the quality model of this process has been discussed.

5). Novel express-method to make the simple detection of the bio-objects forms and their possible deformation can be considered, and prognoses to use this procedure in the biomedicine practices can be extended.

6). Area of the application of the bio-structured liquid crystal materials for the general optoelectronics can be found. Area of the application of the new orienting conducting layers made via LOD technique can be applied in the display technique, too.

7). Some unique approaches proposed in this consideration can possibly be useful in order to collect the new knowledge in the nano- and biomaterials science and to extend the area of the application of the structured organic systems in the education, due to the ability of liquid crystals to show the complex interactions between different materials.

Acknowledgement: This paper research results have been done within the RFBR Grants No. 10-O3oog16 (201O-2012) and No.13-O3-OOO44 (2013-2015) as well as they supported by the FP7 Program, Marie Curie International Researchers Exchange Proposal "BIOMOLEC" (2011-2015). The authors would like to thank their colleague namely Dr. S.V. Serov, and Dr. P.Ya. Vasilyev, (Vavilov State Optical Institute, Saint-Petersburg, Russia) for the useful discussion at the Lab seminars. The authors appreciate Prof. Agnieszka Pawlicka (Instituto de Química de São Carlos, São Carlos, Brazil) and Prof. Chantal Andraud (Laboratoire de Chimie,UMR CNRS 5182, Ecole Normale Suprerieure de Lyon, France) for the opportunity to work with red-fish DNA.

\section{REFERENCES}

1. A. L. Garner, M. Deminsky, V. B. Neculaes, V. Chashihin, A. Knizhnik, B. Potapkin, "Cell membrane thermal gradients induced by electromagnetic fields," Journal of Applied Physics, vol. 113, no. 21, pp. 214701-1 - 214701-11, Jun. 2013. DOI: $10.1063 / 1.4809642$

2. A. K. Sharm, "Plasmonic biosensor for detection of hemoglobin concentration in human blood: Design considerations," Journal of Applied Physics, vol. 114, no. 4, pp. 044701-1 - 044701-8, Jul. 2013. DOI: $10.1063 / 1.4816272$

3. W. Drexler, M. Liu, A. Kumar, T. Kamali, A. Unterhuber, R. A. Leitgeb, "Optical coherence tomography today: speed, contrast, and multimodality," J. Biomed. Opt., vol. 19, no. 7, pp. 071412-1 - 07141234, Jul. 2014.

DOI: 10.1117/1.JBO.19.7.071412 PMid: 25079820

4. M. Li, F. Zhao, J. Zeng, J. Qi, J. Lu, W. Ch. Shih, "Microfluidic surface-enhanced Raman scattering sensor with monolithically integrated nanoporous gold disk arrays for rapid and label-free biomolecular detection," J. Biomed. Opt., vol. 19, no. 11, pp. 111611-1 - 111611-8, Jul. 2014.

DOI: 10.1117/1.JBO.19.11.111611
5. S. Manakasettharn, T. H. Hsu, J. A. Taylor, T. Krupenkin, "Interplay between iridescent and noniridescent coloration in bio-inspired electrically-tunable nanostructures," Optical Materials Express, vol. 4, no. 4, pp. 681-688, Apr. 2014. DOI: $10.1364 / \mathrm{OME} .4 .000681$

6. A. A. Vdovichev, T.S. Sych, Z.V. Reveguk, A. A. Smirnova, D. A. Maksimov, R. R. Ramazanov, A. I. Kononov, "Structure of fluorescent metal clusters on a DNA template," Journal of Physics: Conference Series, vol. 741, pp. 012069-1 - 012069-4, 2016. DOI: $10.1088 / 1742-6596 / 741 / 1 / 012069$

7. N. V. Kamanina and V. N. Kidalov, "A study of the lining up of red blood cells in a nematic liquid crystal medium," Tech. Phys. Lett., vol. 22, no. 7, pp. 571-572, 1996.

8. N. V. Kamanina, "Similarities and differences between the effect of orientation of red blood cells in a nematic liquid-crystal medium and the Fröhlich electrical vibrations," Tech. Phys. Lett., vol. 23, no. 12, pp. 902905, Dec. 1997.

DOI: $10.1134 / 1.1261926$

9. A. A. Kamanin, N. V. Kamanina, "Induced rearrangement of liquid crystal caused by aligning of human erythrocytes," Materials Science Forum, vol. 555, pp. 401-404, Sep. 2007. DOI: 10.4028/www.scientific.net/MSF.555.401

10. A. Kamanin and N. Kamanina, "Self-Organization of Liquid Crystals Induced by Aligning of Human Erythrocytes," Mol. Cryst. Liq. Cryst., vol. 486, no. 1, pp. 50-56, 2008. DOI: $10.1080 / 15421400801917379$

11. N. V. Kamanina, S. V. Serov, Y. Bretonniere, C. Andraud, "Organic Systems and Their Photorefractive Properties under the Nano- and Biostructuration: Scientific View and Sustainable Development," Journal of Nanomaterials, vol. 2015, 2015

DOI: $10.1155 / 2015 / 278902$

12. Н. В. Каманина, П. Я. Васльев, “Оптическое покрытие на основе углеродных нанотрубок для оптического приборостроения и наноэлектроники," Патент на изобретение №2355001, Май 10. 2009. (N. V. Kamanina, P. Ya. Vasilyev, "Optical coatings based on CNTs for the optical devises and nanoelectronics," Patent RU 2355001 C2, May 10, 2009.)

Retrieved from:

http://bd.patent.su/23550002355999/pat/servl/servlet331f.html Retrieved on: Dec. 19, 2016

13. Н. В. Каманина, П. Я. Васльев, В. И. Студенов, "Оптическое покрытие на основе ориентированных в электрическом поле углеродных нанотубок для оптического приборостроения, микро- и наноэлектроники при нивелировании границы раздела сред: твердая подложка-покрытие,” Патент № RU 2405177 C2, Ноя. 27. 2010. (N. V. Kamanina, P. Ya. Vasilyev, V. I. Studeonov, "Optical coating based on oriented in the electric field CNTs for the optical devises, micro- and nanoelectronics under the conditions when the interface: solid substrate-coating can be eliminated," Patent RU 2405177 C2, Nov. 27 2010.)

Retrieved from:

http://www.freepatent.ru/images/patents/57/2405177 /patent-2405177.pdf

Retrieved on: Dec. 16, 2016

14. N. V. Kamanina, Yu. A. Zubtcova, A. A. Kukharchik, C. Lazar, I. Rau, "Control of the IR-spectral shift via modification of the surface relief between the liquid crystal matrixes doped with the lanthanide nanoparticles and the solid substrate," OPTICS EXPRESS, vol. 24, no. 2, pp. A270 - A275, Jan. 2016. DOI: $10.1364 / \mathrm{OE} .24 .00 \mathrm{~A} 270$

PMid: 26832580 
15. N. Kamanina, "Refractive properties of the bio- and nano-structured materials as an indicator of the model matrix macro parameters modification," Radiation and Applications, vol. 2, no. 1, pp. 58 - 61, Apr. 2017.

DOI: 10.21175/radj.2017.01.012 